\title{
Determination of Pesticide-Induced Genotoxicity on Soybean (Glycine max
} L.)

\author{
Asuman DEVECI ÖZKAN", Özlem AKSOY²
}

\begin{abstract}
${ }^{1}$ Department of Medical Biology, Faculty of Medicine, Sakarya University, Sakarya, 54300, Turkey
${ }^{2}$ Department of Biology, Faculty of Science and Literature, Kocaeli University, Kocaeli, 41380, Turkey

ORCID ID: Asuman DEVECİ OZKAN: https://orcid.org/0000-0002-3248-4279; Özlem AKSOY: http://orcid.org/0000-0003-0969-5171
\end{abstract}

\begin{abstract}
Received: 04.09.2019
Accepted: 07.11.2019

Published online: 20.12 .2019

Issue published: 20.12 .2019

Abstract: Pesticides are used in agriculture and cause side effects in plants and can be transported to products which we consume. Genotoxic chemical substances distributed to environment and higher plants such as Glycine max have been used as an indicator plants that show the genotoxic effects of environmental chemical pollutants. In this respect we investigated the potential genotoxic effect of three different pesticides (Pomarsol Forte WP 80 as a fungucide, Arrivo 25 EC as an insecticide, and The End EC as an herbicide) on G. max (Glycine max L.) for the first time. In order to determine the genotoxic effects of these pesticides on G max. Median EC (effective concentration) determination analysis, RAPD-PCR (randomly amplified polymorphic DNA-polymerase chain reaction) assay and protein analysis were used. Our results indicated that The End as a herbicide had more inhibitory effects on G. max root growth compare to the other pesticides. 20 RAPD primers were used, eighteen primers gave stable results while 11 of them were polymorphic and 7 of them showed the same band profile. Percentage of polymorphism was found as $20 \%$. Total protein content was significantly decreased by insecticide treatment but increased in herbicide treatment $(\mathrm{p}<0.05)$. In conclusion these results suggest that these pesticides have genotoxic effects on $G$. max and the use of these chemicals must be reduced to avoid exposure to humans and the environment.
\end{abstract}

Keywords: cypermethrin, quizalofop-p-ethyl, RAPD-PCR, SDS-PAGE, thiram.

\section{Pestisit-Kaynaklı Genotoksisitenin Soya Fasulyesinde (Glycine max L.) Belirlenmesi}

\begin{abstract}
Öz: Pestisitler, tarımsal alanlarda yaygın olarak kullanılırken bitkilerde yan etkilere neden olmaktadır ve tükettiğimiz ürünlere de taşınabilmektedir. Genotoksik kimyasal maddeler çevreye yayılmaktadır ve Glycine max gibi yüksek yapılı bitkiler, kimyasal çevre kirleticilerinin genotoksik etkilerini gösteren indikatör bitkiler olarak kullanılmaktadır. Bu bağlamda, mevcut çalışmada ilk kez üç farklı pestisitin (fungusit olarak Pomarsol Forte WP 80, insektisit olarak Arrivo 25 EC ve herbisit olarak The End EC) potansiyel genotoksik etkisi soya fasulyesi (Glycine max L.) üzerinde araştırılmıştır. G. max üzerindeki genotoksik etkiyi belirlemek için ortalama etkili konsantrasyon (median EC), RAPD-PCR (rastgele amplifiye polimorfik DNA-polimeraz zincir reaksiyonu) ve protein analizleri kullanılmıştır. Elde edilen sonuçlar bir herbisit olarak The END pestisitinin diğerlerine göre G. max kök büyümesi üzerinde daha fazla inhibe edici etkisi olduğu saptanmıştır. 20 RAPD primeri kullanılmış; bunlardan 18 primer stabil sonuç verirken, 11 tanesi polimorfik ve 7 tanesi benzer bant profili göstermiştir. Polimorfizm yüzdesi, \% 20 olarak bulunmuştur. Toplam protein içeriği insektisit muamelesi ile kontrol grubuna göre belirgin şekilde azalırken, herbisit muamelesi sonrası anlamlı olarak artmıştır ( $\mathrm{p}<0.05)$. Sonuç olarak elde edilen veriler bu pestisitlerin $G$. max üzerinde belirgin genotoksik etkilerinin olduğunu ve bu kimyasallara karşı insan ve çevresel maruziyetin atmasından dolayı kullanımdan kaçınılması gerektiğini göstermektedir.
\end{abstract}

Anahtar kelimeler: cypermethrin, quizalofop-p-ethyl, RAPD-PCR, SDS-PAGE, thiram.

\section{Introduction}

Numerous pesticides are widely used in agriculture and their usage has become required; however, incorrect uses of these chemical substance causes side effects in plants (Aksoy, Dana, Sanal, \& Aktaç, 2007). Pesticides are used in different combinations, at different growth times and storage stages to protect agricultural products from harmful organisms (such as fungi) and to obtain high quality products. Pesticides accumulated after processing in food can be transported to products such as baby food (Wang, Chang, Hwang, Turnbull, \& Howard, 2000).

The dithiocarbamate derivative thiram (the active ingredient of Pomarsol Forte $80 \mathrm{WP}$ ) is widely used in agriculture to protect vegetables and prevent mold contamination Cypermethrin (the active ingredient of Arrivo $25 \mathrm{EC}$ ) is a synthetic pyrethroid used to protect the consumption of commercial agricultural land and household products from insects. Quizalofop-p-ethyl (active ingredient of The End) is a phenoxy herbicide used for controlling weeds and in many agricultural lands like lentils (Villani, 1998).

The developments in industry and economy have caused the production of genotoxic chemical substances distributed to the environment which cause harmful effects and even death for human beings Poli et al., 1999). Higher plants have been used as an indicator plants that show the genotoxic effects of environmental chemical pollutants (Angelis, McGuffie, Menke, \& Schubert, 2000; Yıldız \& Arıkan, 2008; Yıldız, Ciğerci, Konuk, Fidan, \& Terzi, 2009).

Evaluating the genotoxic effect through the DNA is more useful because it produces the results in a short time and give precise results. The use of DNA-based techniques to detect changes in DNA sequences is is becoming widespread. Randomly amplified polymorphic DNA (RAPD) is a method that can be used in genotoxicity studies and changes in the RAPD band profile clearly indicate changes betweeen treated and untreated groups

\footnotetext{
*Corresponding author: deveci@sakarya.edu.tr
} 
in DNA levels against genetic agents (Martins, Lopes, Brehm, \& Ribeiro., 2005; Enan, 2006; Liu et al., 2007). In addition, the amount of DNA damage and mutations in bacteria, plants, and animals can be determined through genomic DNA by RAPD as a molecular marker technique (Atienzar, Conradi, Evenden, Jha, \& Depledge, 1999). Thus, the genotoxic effect of toxic chemicals has been regarded to alter genomic template stability through the changes in RAPD band profile (Wang, Lu, \& Shen, 2007; Cenkci et al., 2010).

Our study is aimed to analyze the effect of pesticide pollution on the genetic material of G. max by use of the RAPD-PCR and to analyze the alterations in RAPD band profiles with respect to total protein levels and SDS-PAGE band profiles of whole seed proteins. G. max was used in this study as an experimental material as it is an important agricultural plant worldwide. We thought that obtained results may suggest a tolerable level of toxicity on G. $\max$ against to these pesticides which are used widely in agriculture.

\section{Materials and Methods}

\subsection{Chemicals}

Pomarsol Forte WP 80 (thiram), [bis(dimethylthiocarbamoyl) disulfide] is a type of sulfur fungicide which is a $80 \%$ water-wettable powder produced by Bayer Company, Arrivo 25 EC (cypermethrin), [(RS)-a-cyano-3-phenoxybenzyl (1RS)-cistrans-3-(2,2-dichlorovinyl)-2,2-

dimethylcyclopropanecarboxylate] is a synthetic pyrethroid which is a $25 \%$ emulsifiable solution produced by Hektaş Company and The End EC (Quizalofop-pethyl), [Ethyl (2R)-2-[4-(6-chloroquinoxalin-2yloxy)phenoxy]propionate] is a phenoxy herbicide which is a $5 \%$ emulsifiable solution by Agrogeneral Company were used as pesticides in this study.
2.2. Determination of $\mathrm{EC}_{50}$ and Treatment of G. $\max$ Seeds with Pesticides

G. max seeds (50 smiliar pieces) were germinated in distilled water for $24 \mathrm{~h}$ and treated with ten different concentrations of Pomarsol Forte WP 80 (0.00125, 0.0025, $0.005,0.01,0.02,0.04,0.08,0.16,0.32$ and $0.64 \mathrm{M})$, Arrivo 25 EC $(0.075,0.15,0.3,0.6,1.2,2.4,4.8,9.6,19.2$ ve $38.4 \mathrm{M})$ and The End $(0.0125,0.025,0.05,0.1,0.2,0.4,0.8,1.6,3.2$ ve 6.4 $\mathrm{M})$ for $72 \mathrm{~h}$ to determine $\mathrm{EC}_{50}$ (Effective concentration 50). The control group was only treated with distiled water. The root lengths were measured and $\mathrm{T} / \mathrm{C} \%$ was calculated after treatment for $72 \mathrm{~h}$. After determination of $\mathrm{EC}_{50}$ seeds of G. $\max$ were treated with $\mathrm{EC}_{50}$ and $2 \times \mathrm{EC}_{50}$ concentrations for each pesticide. When the roots were 0.5 $\mathrm{cm}$ or higher, it was accepted as germinated.

2.3. Randomly Amplified Polymorphic DNA- Polymerase Chain Reaction (RAPD- PCR)

G. max roots were grinded in liquid nitrogen and DNA was isolated with DNeasy Plant Mini Kit (Qiagen). DNA concentration was measured at 260/280 nm using spectrophotometrically. Twenty primers (Table 1) were used in RAPD-PCR assay and optimized to Williams, Kubelik, Livak, Rafalski, and Tingey (1990). In order to determine the molecular weights of the RAPD-PCR amplicons 100-bp, DNA ladder was used. An UV imaging device was used to examine the RAPD-PCR band profile and the Vision WorksLS (Version 6.8) software was used to calculate the each amplicon size. Amplification products were scored as presence (1) or absence (0) and only strong bands were used for analysis. Genetic similarity coefficients between the treatment and untreated control groups were calculated according to Nei (1978)'s unbiased measure via POPGENE (version 1.31) software. Genomic template stability (GST) was estimated using the formula of "GST\% = (1-a / n) X 100" (a: RAPD polymorphic bands, $\mathrm{n}$ : total bands of control).

Table 1. List of primers name (ID) and their nucleotide sequences used in the RAPD analysis

\begin{tabular}{|c|c|c|c|c|}
\hline Number of primers & Name of primers & $\begin{array}{l}\text { Sequences of primers } \\
\left(5^{\prime} \rightarrow 3^{\prime}\right)\end{array}$ & $\operatorname{Tm}\left({ }^{\circ} \mathrm{C}\right)$ & Rate of GC \% \\
\hline 1 & AD1 & GTTGCGATCC & 32 & 60 \\
\hline 2 & AD2 & GTGCCTAACC & 32 & 60 \\
\hline 3 & AD3 & ACGCGCATGT & 32 & 60 \\
\hline 4 & $\mathrm{AD} 4$ & GACGCCACAC & 34 & 70 \\
\hline 5 & AD5 & CCAGCTTAGG & 32 & 60 \\
\hline 6 & AD6 & CCCGCTACAC & 34 & 70 \\
\hline 7 & AD7 & GAGCGTCGAA & 32 & 60 \\
\hline 8 & AD8 & TGCGAGAGTC & 32 & 60 \\
\hline 9 & AD9 & CAGCCCAGAG & 34 & 70 \\
\hline 10 & AD10 & TCGCCGCAAA & 32 & 60 \\
\hline 11 & AD11 & GGCACGTAAG & 32 & 60 \\
\hline 12 & AD12 & CCCAGTCACT & 32 & 60 \\
\hline 13 & AD13 & TCGGCGGTTC & 34 & 70 \\
\hline 14 & AD14 & CСАТTССССА & 32 & 60 \\
\hline 15 & AD15 & ACAGGTGCGT & 32 & 60 \\
\hline 16 & AD16 & GGACGACAAG & 32 & 60 \\
\hline 17 & AD17 & CAGAGGTCCC & 34 & 70 \\
\hline 18 & AD18 & TCCGATGCTG & 32 & 60 \\
\hline 19 & AD19 & GTCGTTCCTG & 32 & 60 \\
\hline 20 & AD20 & AAAGGGGTCC & 32 & 60 \\
\hline
\end{tabular}




\subsection{Protein Analysis}

Seed storage total soluble protein isolation was done as described by Saraswati, Matoh, Phupaibul, Lumpkin, \& Kobayashi (1993) after $72 \mathrm{~h}$ of incubation. Following protein extraction, the Bradford Assay method was used to analyze the concentrations of the total soluble proteins present in the seed (Bradford, 1976). The SDS-PAGE of total seed protein was done as described by Laemmli (1970). After SDS-PAGE performed, the gel was visualized using a photo imaging system and the dendrogram was generated by Visionworks (Version 6.8) software based on the presence or absence of polypeptide bands on the SDSPAGE gel.

\subsection{Statistical Analysis}

The data obtained was statistically analyzed using SPSS 16.0 (SPSS Inc., Chicago, IL, USA). One-way analysis of variance (ANOVA) followed by Tukey's multiple comparison test was used and p-values less than 0.05 are considered "statistically significant."

\section{Results and Discussion}

$\mathrm{EC}_{50}$ values were determined $\sim 0.08 \mathrm{M}$ for Pomarsol Forte WP 80 fungicide, $\sim 9.6 \mathrm{M}$ for Arrivo $25 \mathrm{EC}$ insecticide, and $\sim 0.4 \mathrm{M}$ for The End herbicide. Thus, experiments were done using $0.08 \mathrm{M}\left(\mathrm{EC}_{50}\right)$ and $0.16 \mathrm{M}\left(2 \times \mathrm{EC}_{50}\right)$ Pomarsol Forte WP 80 concentrations, $9.6 \mathrm{M}\left(\mathrm{EC}_{50}\right)$ and $19.2 \mathrm{M}$ $\left(2 \times E_{50}\right)$ Arrivo $25 \mathrm{EC}$ concentrations and $0.4 \mathrm{M}\left(\mathrm{EC}_{50}\right)$ and $0.8 \mathrm{M}\left(2 \mathrm{xEC}_{50}\right)$ The End concentrations. It was indicated that The End herbicide had more inhibitory effects on $G$ max. seedlings compare to the Pomarsol Forte WP 80 fungicide and Arrivo $25 \mathrm{EC}$ insecticide.

The End herbicide, Pomarsol Forte WP 80 fungicide, and Arrivo 25 EC insecticide are widely used in G. max agricultural applications. The genotoxic effects of these pesticides on G. max were investigated for the first time and their possible genotoxic effects were determined. Also studies involving possible genotoxic effects of pesticides on plants are limited to several plant species and need to be expanded.

In order to determine the genotoxic effects of different three pesticides, the RAPD analysis was used between treated and untreated groups with pesticides. Twenty primers (60-70\% GC content) were used for evaluating the changes on genomic DNA. Eighteen primers gave stable results while 11 of them were polymorphic and 7 of them showed the same band profile. Additionally, 11 polymorphic RAPD primers showed differences (disappearance and/or appearance) in band profiles between pesticides treated and untreated groups (Fig. 1). Totally 55 bands of untreated group and 308 bands of treated groups were obtained ranged from 146 to 1077 bp. RAPD profile changes of treated and untreated groups were shown in Table 2 compared with their control groups. Value of polymorphisms P (\%) was found $20 \%$. It was suggested that the changes in RAPD profile as in Fig. 1 , polymorphism was due to the loss and/or gain of the bands in pesticide treated groups compared to the control RAPD band profiles. Obtained results indicated that DNA damage may be serious in the G. max root cells after the treatment of these pesticides. When we consider the reasons for the loss or gain of the band causing polymorphism, it can be seen that these conditions may be due to breaks in DNA, modified bases, bulky adducts, DNA-protein cross-links or point mutations (Atienzar Venier, Jha, \& Depledge, 2002; Wolf, Blust, \& Backeljau, 2004). Appearance and disappearance of bands were found in our RAPD profiles in pesticide treated groups and it can be attributed to mutations and DNA damage on G. max (Atienzar \& Jha, 2006).

Table 2. The number of bands in control and molecular sizes (base pair, bp) of disappearance (-) and/or appearance (+) of DNA bands for all primers of pesticide-treated germinated root tips of soybean using UVI soft image analyzer software.

\begin{tabular}{|c|c|c|c|c|c|c|c|c|}
\hline \multirow[b]{2}{*}{ Primers } & \multirow[b]{2}{*}{ Control } & & \multicolumn{2}{|c|}{ Pomarsol Fotre WP 80} & \multicolumn{2}{|l|}{ Arrivo 25 EC } & \multicolumn{2}{|l|}{ The End EC } \\
\hline & & & PX & $\mathbf{P 2 X}$ & $\mathbf{A X}$ & A2X & TX & $\mathrm{T} 2 \mathrm{X}$ \\
\hline \multirow{2}{*}{ AD-1 } & \multirow{2}{*}{5} & - & 636 & 636 & 0 & 0 & 0 & 0 \\
\hline & & + & $848 ; 471$ & 848 & $1077 ; 848 ; 636 ; 351$ & $1077 ; 848 ; 351$ & $381 ; 906 ; 1077$ & $381 ; 906 ; 1077$ \\
\hline \multirow{2}{*}{ AD-3 } & \multirow{2}{*}{5} & - & 0 & 0 & 0 & 0 & 0 & 0 \\
\hline & & + & 0 & 0 & 825 & 0 & 0 & 0 \\
\hline \multirow{2}{*}{$\mathrm{AD}-4$} & \multirow{2}{*}{6} & - & 854 & 854 & 626 & 626 & 854 & $345 ; 420 ; 854$ \\
\hline & & + & 0 & 0 & 0 & 854 & 0 & 0 \\
\hline \multirow{2}{*}{ AD-5 } & \multirow{2}{*}{3} & - & 0 & 0 & 325 & 325 & 0 & 0 \\
\hline & & + & 0 & 0 & 0 & 0 & 0 & 0 \\
\hline \multirow{2}{*}{ AD-7 } & \multirow{2}{*}{5} & - & 0 & 0 & 0 & $357 ; 488$ & 0 & 0 \\
\hline & & + & 0 & 0 & 0 & 0 & 396 & 396 \\
\hline \multirow{2}{*}{ AD-8 } & \multirow[b]{2}{*}{6} & - & 0 & 0 & 0 & 422 & 276 & 276 \\
\hline & & + & 0 & 0 & 0 & 0 & $715 ; 833$ & $715 ; 833$ \\
\hline \multirow{2}{*}{ AD-10 } & \multirow{2}{*}{5} & - & 0 & 0 & 325 & $252 ; 325$ & 0 & 0 \\
\hline & & + & 0 & 0 & 0 & 628 & 1264 & 0 \\
\hline \multirow{2}{*}{ AD-13 } & \multirow{2}{*}{3} & - & 0 & 1086 & 0 & 0 & 146 & 146 \\
\hline & & + & 0 & 0 & 0 & $447 ; 538$ & 0 & 0 \\
\hline \multirow{2}{*}{ AD-15 } & \multirow[b]{2}{*}{7} & - & 0 & 0 & $418 ; 454$ & $418 ; 454$ & 0 & 0 \\
\hline & & + & 0 & 0 & 0 & 0 & 0 & 0 \\
\hline \multirow{2}{*}{ AD-17 } & \multirow{2}{*}{5} & - & 0 & 0 & 0 & 0 & 0 & 0 \\
\hline & & + & 385 & 385 & 0 & 0 & 0 & 0 \\
\hline \multirow{2}{*}{ AD-20 } & \multirow{2}{*}{5} & - & 0 & 0 & 252 & 252 & 248 & 248 \\
\hline & & + & 0 & 769 & 0 & 0 & 0 & 0 \\
\hline Total & 55 & & $2(-) ; 3(+)$ & $3(-) ; 3(+)$ & $6(-) ; 5(+)$ & $7(-) ; 10(+)$ & $4(-) ; 7(+)$ & $6(-) ; 6(+)$ \\
\hline
\end{tabular}

*PX: 0.08 M, P2X: 0.16 M, AX: 9.6 M, A2X: 19.2 M, TX: 0.4 M and T2X: 0.8 M

Additionally, GTS values were calculated for each polymorphic 11 primers and shown in Table 3. The average highest decrease in GTS value $(76.9 \%)$ was calculated in $19.2 \mathrm{M}$ Arrivo $25 \mathrm{EC}$ insecticide treatment and GTS values were decreased in all the highest pesticide treatment compared to the untreated control groups. DNA damage, success in repair, and replication of DNA are related in GTS value. Our results showed that GTS values were decreased in all pesticide treatments compared to the untreated control groups. However we cannot say that it is related to the high DNA damage of pesticides because efficacy of DNA repair and DNA replication are 
suppressed via the high level of DNA damage (Atienzar \& Jha, 2006).

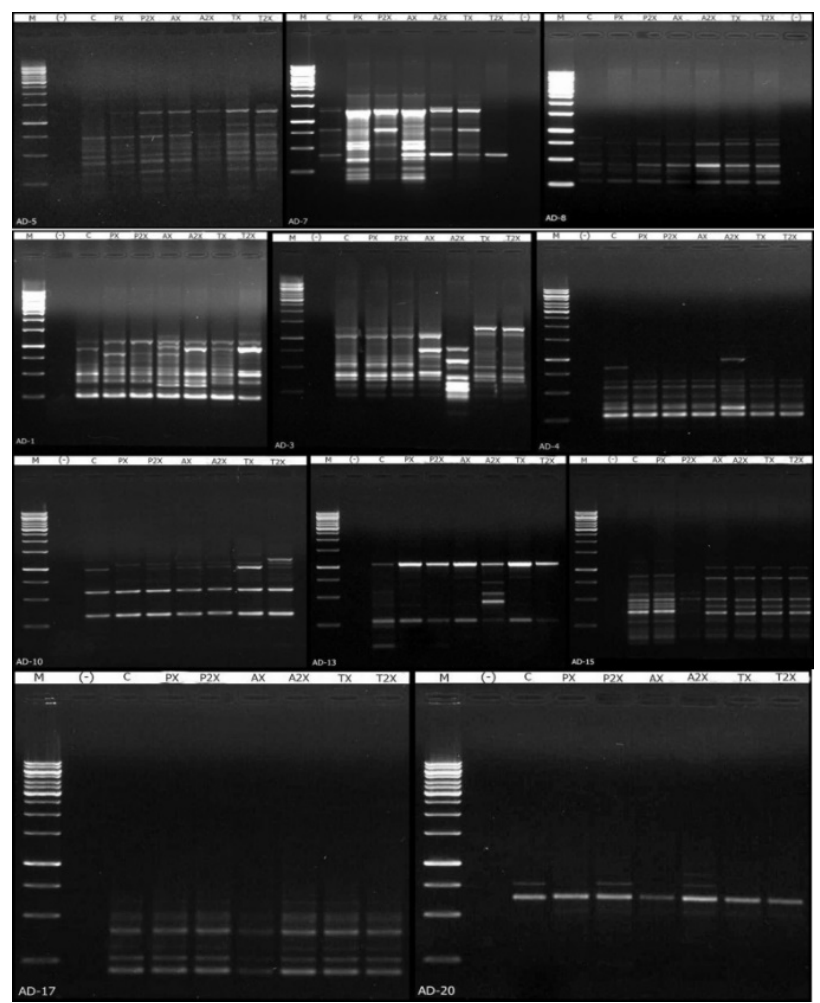

Figure 1. Polymorphic RAPD profiles of pesticide-treated germinated root tips of soybean generated using with primer $\mathrm{AD}$ 1, AD-3, AD-4, AD-5, AD-7, AD-8, AD-10, AD-13, AD-15, AD-17 and AD-20. [C: Control, PX: 0.08 M Pomarsol Forte 80 WP, P2X: 0.16 M Pomarsol Forte 80 WP, AX: 9.6 M Arrivo 25 EC, A2X: 19.2 M Arrivo 25 EC, TX: 0.4 M The End EC, T2X: 0.8 M The End EC, M: GeneRuler $100 \mathrm{bp}$ plus DNA Ladder (100-3000 bp)].

The band profiles of G. $\max$ seeds exposed to different pesticides after SDS-PAGE were shown on Fig. 2. After the treatment of different pesticides, there is a statistically significant reduction in insecticide treatment but a significant increase in herbicide treatment in protein amount of G. $\max (\mathrm{p}<0.05)$ (Fig. 3). The dendogram obtained by the evaluation of all protein bands after SDSPAGE analysis and the genetic distance values were shown on Fig. 4. SDS-PAGE analysis showed that there were changes in protein profiles between the different pesticide treatments groups compared to the untreated control group.

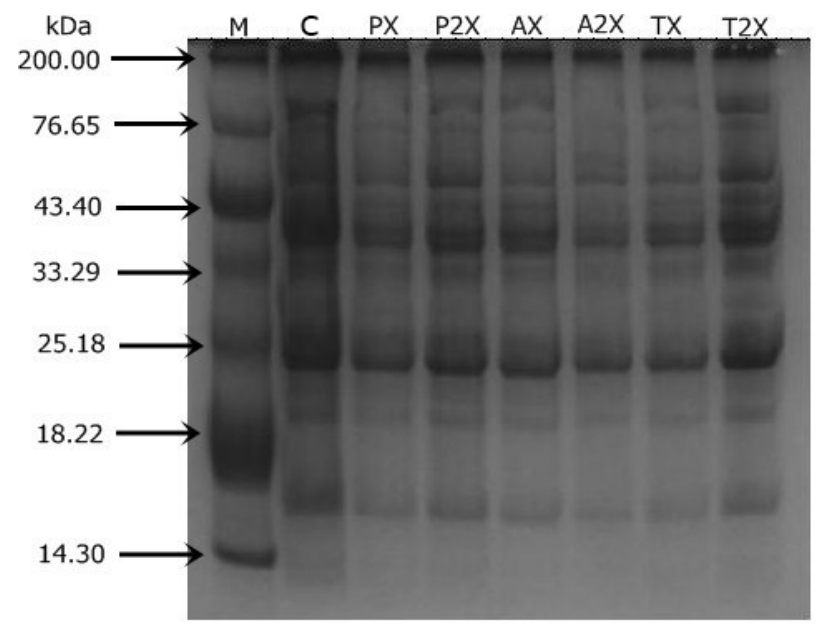

Figure 2. The band profiles of soybean seeds exposed to different pesticides after SDS-PAGE (M: Marker C: Control, PX: $0.08 \mathrm{M}$ Pomarsol Forte 80 WP, P2X: 0.16 M Pomarsol Forte 80 WP, AX: 9.6 M Arrivo 25 EC, A2X: 19.2 M Arrivo 25 EC, TX: 0.4 M The End EC and T2X: 0.8 M The End EC)

It is known that total protein content of cells is an important indicator of various changes in metabolism and changes in response to various environmental pollutants (Singh \& Tewari, 2003). It has been showed that various pesticides reduce total protein content in various organisms like Brassica juncea L. or Aporrectodea caliginosa (Singh \& Tewari, 2003; Moshley, Ismail, \& Ahmed, 2003). In this study, changes in total protein content of G. max roots treated with different pesticides showed an inverse relationship with the pesticide type and we thought that this change is a respond to these pesticides that were used.

Table 3. Genomic template stability (GTS, \%) values.

\begin{tabular}{|c|c|c|c|c|c|c|c|}
\hline \multirow[b]{2}{*}{ Primers } & \multirow[b]{2}{*}{ Control } & \multicolumn{2}{|c|}{ Pomarsol Forte $80 \mathrm{P}$} & \multicolumn{2}{|c|}{ Arrivo 25 EC } & \multicolumn{2}{|c|}{ The End EC } \\
\hline & & PX & P2X & $\mathbf{A X}$ & A2X & TX & $\mathrm{T} 2 \mathrm{X}$ \\
\hline AD-1 & 100 & 40.0 & 60.0 & 100 & 100 & 100 & 100 \\
\hline AD-3 & 100 & 100 & 100 & 80.0 & 100 & 100 & 100 \\
\hline AD-4 & 100 & 83.3 & 83.3 & 83.3 & 66.6 & 83.0 & 50.0 \\
\hline AD-5 & 100 & 100 & 100 & 66.6 & 66.6 & 100 & 100 \\
\hline AD-7 & 100 & 100 & 100 & 100 & 40.0 & 60.0 & 60.0 \\
\hline AD-8 & 100 & 100 & 100 & 100 & 83.3 & 50.0 & 50.0 \\
\hline AD-10 & 100 & 100 & 100 & 80.0 & 40.0 & 80.0 & 100 \\
\hline AD-13 & 100 & 100 & 66.6 & 100 & 100 & 83.3 & 83.3 \\
\hline AD-15 & 100 & 100 & 100 & 71.6 & 71.6 & 100 & 100 \\
\hline AD-17 & 100 & 80.0 & 80.0 & 100 & 100 & 100 & 100 \\
\hline AD-20 & 100 & 100 & 80.0 & 80.0 & 80.0 & 80.0 & 80.0 \\
\hline Average & 100 & 91.1 & 88.0 & 87.2 & 76.9 & 85.0 & 83.9 \\
\hline
\end{tabular}

*PX: 0.08 M, P2X: 0.16 M, AX: 9.6 M, A2X: 19.2 M, TX: 0.4 M and T2X: 0.8

In conclusion, plants are directly exposed to pesticides as well as soil, water, and air. Moreover, pesticides are very reactive molecules and they can modify the cellular structures, especially DNA. The present finding supports the claim that these pesticides made a genetic modification on G. max seeds and roots. Pesticides have toxic effects on human and the environment, because they accumulate on plants and show toxic effects, exactly resulting with DNA damage. Pesticides have a wide range of usage in different G. max and other plants on agricultural areas and these are discharged into the environment, plants, humans, and so into ground waters. Pesticides are very important due to the mutagenic effects on plants and humans. Therefore, the usage of pesticides should be considered carefully and reduced in order to decrease their exposure to humans and environment. 
Further molecular studies are needed to evaluate the genotoxic effects of these chemicals.

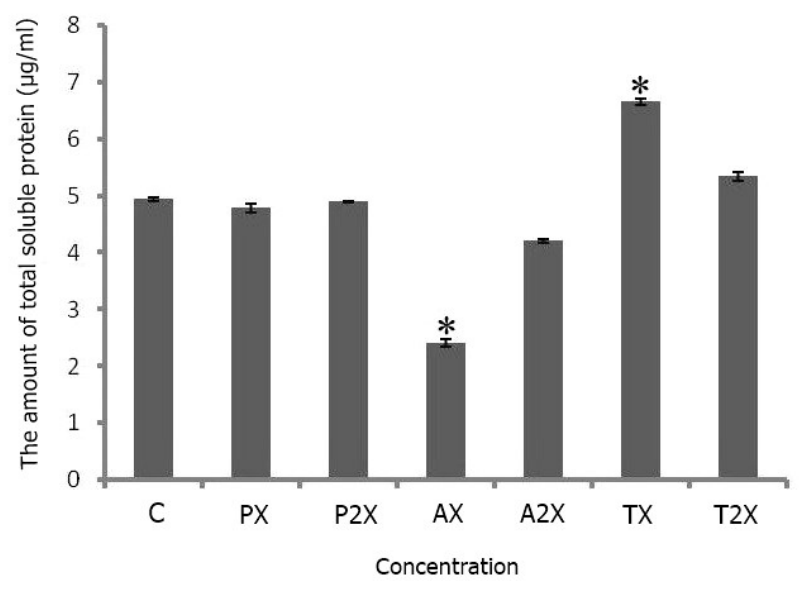

Figure 3. The effects of different pesticide applications on total protein amount in soybean seeds. The values are significantly different at $p<0.05$ compared with the control group. (PX: $0.08 \mathrm{M}$ Pomarsol Forte 80 WP, P2X: 0.16 M Pomarsol Forte 80 WP, AX: 9.6 M Arrivo 25 EC, A2X: 19.2 M Arrivo 25 EC, TX: 0.4 M The End EC, T2X: 0.8 M The End EC).

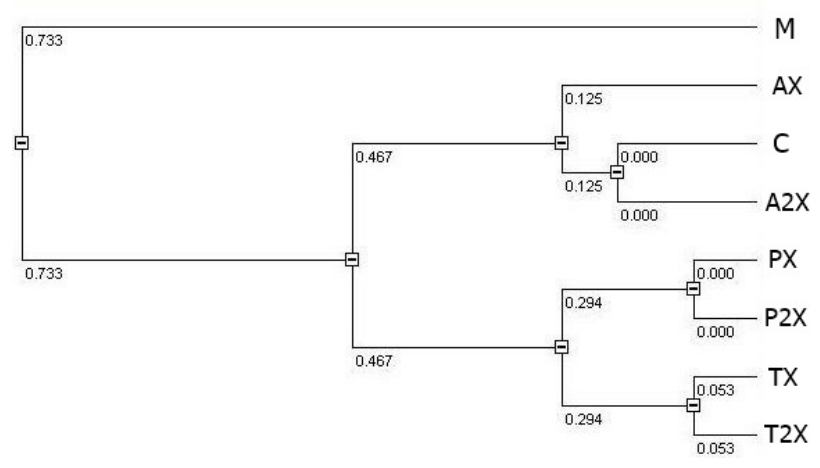

Figure 4 . The dendogram obtained by the evaluation of all protein bands after SDS-PAGE (M: Marker, C: Control, PX: $0.08 \mathrm{M}$ Pomarsol Forte 80 WP, P2X: 0.16 M Pomarsol Forte 80 WP, AX: 9.6 M Arrivo 25 EC, A2X: 19.2 M Arrivo 25 EC, TX: 0.4 M The End EC, T2X: 0.8 M The End EC)

Acknowledgments: This study is supported by Kocaeli University Scientific Research Projects Coordination Unit. Project Number: 2011/43.

\section{References}

Aksoy, O., Dane, F., Sanal F.E., \& Aktac, T. (2007). The effects of Fusilade (Fluazifop p-butyl) on germination, mitotic frequency and a-amylase activity of lentil (Lens culinaris Medik.) seeds. Acta Physiologia Plantarium, 29, 115-120.

Angelis K.J., McGuffie, M., Menke, M., \& Schubert, I. (2000). Adaption to alkylation damage in DNA measured by the comet assay. Environmental Molecular Mutagenesis, 36, 146-150.

Atienzar, F.A., \& Jha, A.N. (2006). The random amplified polymorphic DNA (RAPD) assay and related techniques applied to genotoxicity and carcinogenesis studies: a critical review. Mutation Research, 613, 76-102.

Atienzar, F.A., Conradi, M., Evenden, A., Jha A., \& Depledge, M. (1999). Qualitative assessment of genotoxicity using random amplified polymorphic DNA: comparison of genomic template stability with key fitness parameters in Daphnia magna exposed tobenzo(a)pyrene. Environmental Toxicology and Chemistry, 18, 2275-2282.

Atienzar, F.A., Venier, P., Jha, A.N., \& Depledge M.H. (2002). Evaluation of the random amplified polymorphic DNA (RAPD) assay for the detection of DNA damage and mutations. Mutation Research, 521, 151163.

Bradford, M.M. (1976). A rapid and sensitive method for the quantitation of microgram quantities of protein utilizing the principle of protein-dye binding, Analytical Biochemistry, 72, 248-254.
Cenkci, S., Cigerci, I.H., Yıldız, M., Ozay, C., Bozdağ A., \& Terzi, H. (2010). Lead contamination reduces chlorophyll biosynthesis and genomic template stability in Brassica rapa L. Environmental Experimental Botany, 67, 467-473.

Enan, M.R. (2006). Application of random amplified polymorphic DNA (RAPD) to detect the genotoxic effect of heavy metals. Biotechnology and Applied Biochemistry, 43, 147-154.

Laemmli, U.K. (1970). Cleavage of structural proteins during the assembly of the head of bacteriophage T4. Nature, 227, 680-5.

Liu, W., Yang, Y. S., Zhou, Q., Xie, L., Li, P., \& Sun, T. (2007). Impact assessment of cadmium contamination on rice (Oryza sativa L.) seedlings at molecular and population levels using multiple biomarkers. Chemosphere, 67, 1155-1163.

Martins, N., Lopes, I., Brehm, A., \& Ribeiro, R. (2005). Cytochrome B gene partial sequence and RAPD analysis of two Daphnia longispina lineages differing in their resistance to copper. Bulletin of Environmental Contamination and Toxicology, 74, 755-760.

Mosleh, Y.Y., Ismail, S.M., \& Ahmed M.T. (2003). Comparative toxicity and biochemical responses of certain pesticides to the mature earthworm Aporrectodea caliginosa under laboratory conditions. Environmental Toxicology, 18, 338-346.

Nei, M. (1978). Estimation of average heterozygosity and genetic distance from a small number of individuals. Genetics, 89, 583-590.

Poli, P., Buschini, A., Restivo, F.M., Ficarelli, A., Cassoni, F., Ferrero, I., \& Rossi, C. (1999). Comet assay application in environmental monitoring: DNA damage in human leukocytes and plant cells in comparison with bacterial and yeast tests. Mutagenesis, 14, 547-556.

Saraswati, R., Matoh, T., Phupaibul, P., Lumpkin, T.A., \& Kobayashi, M. (1993). Identification of Sesbania species from electrophoretic patterns of seed protein. Tropical Agriculture (Trinidad), 70, 282-285.

Singh, P.K, \& Tewari, R.K. (2003). Cadmium toxicity induced changes in plant water relations and oxidative metabolism of Brassica juncea L. plants. Journal of Environmental Biology, 24, 107-112.

Villani, P. (1998). The dithiocarbamate derivative thiram has currently widespread use as a contact fungicide for the pro-tection of vegetable crops and for mould control in a variety of fields. Food Chemical Toxicology, 36, 155-164.

Wang, H., Chang, K.F., Hwang, S.F., Turnbull, G.D., \& Howard, R.J. (2000). Effects of root inoculation and fungicide soil drenches on sclerotinia blight of coneflower. Canadian Journal of Plant Science, 80, 909-915.

Wang, J., Lu, Y., \& Shen G. (2007). Combine deffects of cadmium and butachloron soil enzyme activities and microbial community structure. Environmental Geology, 51, 1221-1228.

Williams, J.G.K., Kubelik, A.R., Livak, K.J., Rafalski, J.A., \& Tingey S.V., (1990). DNA polymorphisms amplified by arbitrary primers are useful as genetic markers. Nucleic Acids Research, 18, 6531-6535.

Wolf, H.D., Blust, R., \& Backeljau, T. (2004). The use of RAPD in ecotoxicology. Mutation Research, 566, 249-262.

Yıldız, M., \& Arıkan, E.S. (2008). Genotoxicity testing of quizalofop-P-ethyl herbicide using the Allium cepa anaphase-telophase chromosome aberration assay. Caryologia, 61, 45-52.

Yıldız, M., Cigerci, I. H., Konuk, M., Fidan, A.F. \& Terzi, H. (2009). Determination of genotoxic effects of copper sulphate and cobalt chloride in Allium cepa root cells by chromosome aberration and comet assays. Chemosphere, 75, 934-938. 